\title{
Sedativi u veterinarskoj medicini î njihovo određivanje
}

\author{
A. Puntarić, Đ. Božić Luburić, I. Varenina, N. Bilandžič , M. Krpan i \\ M. Hruškar
}

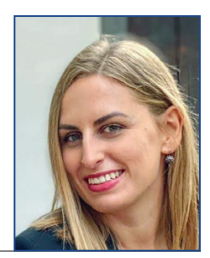

\section{Sažetak}

Sedativi, kao veterinarsko-medicinski proizvodi koji se koriste na životinjama za proizvodnju hrane netom prije samog klanja životinje, predstavljaju potencijalni rizik za zdravlje potrošača zbog povećane mogućnosti zaostajanja njihovih rezidua u proizvodima životinjskog podrijetla. Zbog zaštite javnog zdravstva bitno je provoditi redovitu kontrolu prehrambenih proizvoda, uz korištenje adekvatnih i pouzdanih analitičkih metoda s kojima bi se otkrila moguća odstupanja od propisanih vrijednosti. Zaostajanje rezidua sedativa $\mathrm{u}$ organizmu tretiranih životinja ovisi o mnogim čimbenicima, kao što su: vrsta primijenjenog sedativa, vrsta životinje na kojoj se sedativ primijenjuje, početna primijenjena doza, način i mjesto primjene, zdravstveno stanje životinje itd. Da bi se rezidue mogle transparentno određivati, treba uspostaviti ciljni organ ili tkivo za njihovo određivanje. $\mathrm{Na}$ temelju literaturnih podataka bubrezi su se ispostavili kao najčešće korišteni ciljni organi koji daju pravu sliku o količini prisutnih rezidua. Analitičke metode koje se koriste za određivanje rezidua sedativa mogu biti orijentacijske (imunološki testovi - ELISA) i potvrdne (kromatografske metode poput plinske, tankoslojne, tekućinske kromatografije/tekućinske kromatografije povezane $s$ masenom spektrometrijom). Standard za njihovo određivanje je tekućinska kromatografija povezana $\mathrm{s}$ masenom spektrometrijom. Ova je metoda poznata kao najpouzdanija metoda za određivanje rezidua raznih kontaminanata u biološkim uzorcima, a ne samo sedativa. $U$ današnje se vrijeme sve više koristi tekućinska kromatografija ultra visoke djelotvornosti (UHPLC, engl. Ultra High Performance Liquid Chromatohraphy) koja u usporedbi s uobičajenim tekućinskim kromatografijama ima veću osjetljivost, preciznost i razlučivost. Stoga UHPLC-MS/ MS metoda sa svojom visokom osjetljivošću i selektivnošću prednjači pred drugih dostupnih metoda. U ovom će radu biti opisani neki od najčešće korištenih sedativa na životinjama za proizvodnju hrane, zajedno s načinima određivanja njihovih rezidua.

Ključne riječi: monitoring, rezidue, sedativi, UHPLC-MS/MS, veterinarsko-medicinski proizvodi

Ada PUNTARIĆ, mag. ing. techn. aliment., Prehrambeno-biotehnološki fakultet Sveučilišta u Zagrebu, Hrvatska; Đurđica BOŽIĆ LUBURIĆ, dipl. ing. biotehnol., dr. sc. Ivana VARENINA, dipl. ing. biotehnol., znanstvena suradnica; dr. sc. Nina BILANDZIĆ* dipl. ing. biotehnol., znanstvena savjetnica u trajnom zvanju* (dopisni autor, e-mail: bilandzic@veinst.hr), Hrvatski veterinarski institut, Zagreb, Hrvatska; dr. sc. Marina KRPAN, dipl. ing. preh. tehnol., izvanredna profesorica, dr. sc. Mirjana HRUŠKAR, dipl. ing. biotehnol., redovita profesorica, Prehrambeno-biotehnološki fakultet Sveučilišta u Zagrebu, Hrvatska 


\section{Uvod}

Veterinarsko-medicinski proizvodi su rasprostranjeni u uzgoju životinja i proizvodnje hrane životinjskog podrijetla. Zbog koristi koje pružaju, čime ujedno i olakšavaju uzgoj životinja u današnje vrijeme, može se reći kako je moderna proizvodnja hrane gotovo nezamisliva bez njih. Pritom je bitno da uzgajivači životinja i proizvođači hrane upotrebljavaju iste u skladu s propisanim mjerama. Često nepridržavanje razdoblja karence dovodi do toga da veterinarskomedicinski proizvodi zaostaju u hrani životinjskog podrijetla u obliku rezidua koje pritom mogu potencijalno štetiti zdravlju potrošača. Stoga je u cilju zaštite zdravlja potrošača i osiguravanja zdravstveno ispravne i sigurne hrane određena najviša dopuštena količina (NDK) rezidua pojedinih veterinarskomedicinskih proizvoda $\mathrm{u}$ životinjskim tkivima, organima i drugim proizvodima životinjskog podrijetla. Među njima su i sedativi, veterinarsko-medicinski proizvodi korišteni s ciljem smirivanja i opuštanja životinje, ponajviše prije klanja, da bi se spriječio stres životinja koji, kao takav, posljedično može negativano utjecajti na kakvoću mesa (Cerkvenjak Flajs i MacNeil, 2017.), ali predstavljaju i rizik za zdravlje potrošača, prije svega zbog korištenja trenutak prije klanja (prilikom prijevoza do klaonice) (Trevisani i sur., 2019.).

$\mathrm{Da}$ bi se otkrilo postoje li nesukladnosti u uzorcima životinjskog podrijetla, potrebno je provoditi redoviti monitoring istih, uz korištenje analitičkih metoda koje su sposobne kvantificirati i nedvojbeno identificirati rezidue pri bilo kojim, čak i najmanjim koncentracijama. Postoje literaturni podatci o određivanju rezidua sedativa u biološkim uzorcima uz pomoć tekućinske/plinske kromatografije (Cerkvenjak Flajs i MacNeil, 2017.) ili ELISA testova (Cooper i sur., 2004.). Danas je standard za njihovo određivanje tekućinska kromatografija povezana s masenom spektrometrijom (LC-MS/MS) koja prednjači s visokom osjetljivosti i specifičnosti (Robert i sur., 2013., Oliveira i sur., 2016., Rocca i sur., 2017.).

U ovom će radu bit opisani neki od najčešće korištenih sedativa na životinjama za proizvodnju hrane. Određivanje njihovih rezidua $u$ proizvodima životinjskog podrijetla je od velikog značenja za javno zdravstvo te se velika pažnja usmjerava na njihov monitoring. Bubrezi životinja, su se kao organi s najvišim mjerljivim koncentracijama rezidua sedativa, pokazali najpodobnijim organima za njihovo određivanje.

\section{Veterinarsko-medicinski proizvodi}

„Veterinarsko-medicinski proizvod (VMP) je svaka tvar ili kombinacija tvari za koju se tvrdi da ima svojstvo liječenja i sprečavanja bolesti životinja ili svaka tvar ili kombinacija tvari koje se mogu rabiti ili primijeniti na životinjama u svrhu obnavljanja, ispravljanja ili prilagodbe fizioloških funkcija farmakološkim, imunološkim ili metaboličkim djelovanjem ili postavljanjem medicinske dijagnoze" (Europska komisija, 2001.). VMP se koriste u čitavom svijetu i može se reći da je moderna proizvodnja hrane nezamisliva bez njih, bilo da se koriste $u$ svrhu terapije ili profilakse, modifikacije fizioloških funkcija ili poboljšanja rasta i produktivnosti životinje. Njihovim se korištenjem osigurava sigurna hrana $\mathrm{s}$ visokim prihodima i niskim gubitcima (Falowo i Akimoladum, 2019.). To je od velike važnosti zbog konstantno rastuće svjetske populacije te je potrebno osigurati dovoljne količine hrane (Beyene, 2016.). Primjerice, potreba za mesom i drugim proizvodima od životinja intenzivno raste te se smatra da će do 2050. godine prosječna potrošnja mesa po 
glavi stanovnika biti otprilike $86 \mathrm{~kg}$, što je dvostruko više od procijenjene potrošnje mesa po glavi stanovnika danas $(42,9 \mathrm{~kg})$ (Falowo i Akimoladum, 2019.).

Svaki VMP, koji se koristi, treba biti odobren za uporabu na životinjama za proizvodnju hrane te analiziran na sve potencijalno štetne učinke koji bi se mogli pojaviti u ljudi koji konzumiraju meso i druge proizvode od životinja tretiranih VMP (Trevisani i sur., 2019.). Isto tako, svaki uzgajivač životinja namijenjenih prehrani ljudi treba voditi i čuvati evidenciju o liječenju životinja do pet godina nakon primjene VMP-a (Europska komisija, 2001.). Naime, u proizvodima životinjskog podrijetla nerijetko zaostaju rezidue korištenih VMP-a. Reziduama nazivamo ostatke tvari s farmakološkim djelovanjem, ostatke njihovih metabolita i drugih tvari koje mogu zaostati u životinjskim organima, tkivima i proizvodima i kao takve mogu biti štetne za zdravlje ljudi (Zakon, 2013.). Iako u pravilu proizvodi životinjskog podrijetla ne bi smjeli sadržavati rezidue korištenih VMP-a jer se oni u organizmu životinja metaboliziraju $\mathrm{s}$ ciljem što lakšeg uklanjanja iz organizma putem urina ili izmeta; određena količina rezidua može zaostati i biti detektirana u organima i tkivima tretiranih životinja (Beyene, 2016.). U cilju zaštite zdravlja potrošača, određena je i najviša dopuštena količina (NDK) rezidua (MRL, engl. Maximum Residue Level) VMP-a koje zaostaju u organima i tkivima tretiranih životinja ili u proizvodima životinjskog podrijetla (Trevisani i sur., 2019.). U Europskoj uniji (EU) najviše dopuštene količine rezidua farmakološki djelatnih tvari u hrani životinjskog podrijetla određene su Uredbom Komisije br. 37/2010 (Europska komisija, 2010.).

Postoje brojni čimbenici koji mogu utjecati na pojavu ostataka VMP-a u hrani životinjskog podrijetla kao što su: vrsta, sastav, način i mjesto primjene VMP-a, početna primijenjena doza
(Trevisani i sur., 2019). Metabolizam i opće stanje tretirane životinje te kemijska interakcija među lijekovima koji se koriste na životinjama (Beyene, 2016.). Iako su u pravilu prisutni u relativno malim količinima i ne nužno toksičnima, dugotrajno i kontinuirano unošenje rezidua VMP-a u ljudski organizam hranom životinjskog podrijetla predstavlja ozbiljan rizik za zdravlje i sigurnost potrošača (Beyene, 2016.). Problem nastaje i kada je koncentracija rezidua iznad najviše dopuštene količine. U većini slučajeva jedan od razloga pojavnosti rezidua VMP-a, uz nepridržavanje preporučenih doza i neispravan način primjene, jest i nepoštivanje karence lijeka, odnosno vremena koje je potrebno da se lijek $\mathrm{u}$ organizmu razgradi do dopuštene razine i/ili izluči iz organizma liječenih životinja.

Postoji niz literaturnih podataka i znanstvenih studija koje su dokazale štetnost rezidua VMP-a prisutnih u hrani životinjskog podrijetla. Primjerice, prema Falowo i Akimoladumu (2019.), posljedice unosa rezidua $\mathrm{u}$ organizam čovjeka povezuju se s razvojem antimikrobne rezistencije, poremećajima intestinalne mikroflore, razvitkom alergija ili hipersenzibilnosti pa čak i mutagenim, teratogenim $\mathrm{i}$ kancerogenom djelovanjem. Povećanjem svijesti potrošača o utjecaju rezidua VMP-a na zdravlje narušeno je i njihovo povjerenje prema hrani životinjskog podrijetla, tako da zaostajanje rezidua VMP-a indirektno utječe i na globalnu ekonomiju (Falowo i Akimoladum, 2019.).

\section{Monitoring rezidua veterinarsko-medicinskih proizvoda}

„Proizvodi životinjskog podrijetla koji su namijenjeni prehrani ljudi ne smiju se stavljati u promet ukoliko 
sadrže ili sadrže u količinama većim od dopuštene propisima Europske unije, rezidue i druge kontaminante škodljive za ljudsko zdravlje. Posjednici životinja, veterinarski djelatnici te proizvođači hrane životinjskog podrijetla moraju se pridržavati propisanih preventivnih mjera i određenih rokova karencije, prilikom uporabe veterinarskomedicinskih proizvoda i drugih tvari kako bi se spriječila pojava rezidua. Pravilnikom se određuju najviše dopuštene količine rezidua i drugih kontaminanata $\mathrm{u}$ izlučevinama, tjelesnim tekućinama, dlaci i proizvodima živih životinja te organima i tkivima zaklanih životinja, vodi i hrani za životinje, ako nisu propisani propisima EU." (Članak 93. Zakona o veterinarstvu, 2013.).
Da bi se smanjio sveukupan broj proizvoda životinjskog podrijetla koji sadrže rezidue VMP-a u koncentracijama višim od najviše dopuštene količine, a samim time se smanjio i rizik za zdravlje potrošača, potrebno je provoditi monitoring, odnosno praćenje istih.

Provođenjem obveznih planova za monitoring otkrivaju se i ilegalne uporabe ili zlouporabe odobrenih VMP-a koji se koriste na životinjama za proizvodnju hrane te istražuju razlozi nesukladnosti s propisanim vrijednostima (EFSA, 2020.a). Na razini Republike Hrvatske provodi se Državni program monitoringa rezidua (DPMR). U tom programu "propisan je način odabira i uzimanja uzoraka gdje su uzimani uzorci živih životinja koje su zdrave i/ili proizvoda životinjskog

Tabela 1. Tvari ili skupina tvari čije se rezidue određuju u okviru monitoringa (Pravilnik, 2008.)

\section{SKUPINA A}

Tvari koje imaju anabolički učinak te njihove soli i esteri

\section{Stilbeni, derivati stilbena i njihove soli i esteri}

\section{Antitireoidne tvari}

\section{Steroidi}

4. Laktoni rezorcilne kiseline uključujući zeranol

5. Beta-agonisti

6. Tvari navedene u Pravilniku o najvećim dopuštenim količinama rezidua veterinarskomedicinskih proizvoda u hrani životinjskog podrijetla preuzete su odredbe Uredbe 2377/90 od 26. lipnja 1990. koja predviđa postupak Zajednice za određivanje najviših graničnih vrijednosti ostataka lijekova u uporabi u veterinarskoj medicini u prehrambenim proizvodima životinjskog podrijetla.

\section{SKUPINA B}

\section{Veterinarski lijekovi i kontaminanti}

luključujući i nedopuštene tvari koje mogu biti korištene u veterinarske svrhel

1. Antibakterijske tvari uključujući sulfonamide i kinolone

2. Drugi veterinarski lijekovi:
(a) Antihelmintici
(b) Kokcidiostatici, uključujući nitroimidazole
(c) Karbamati i piretroidi
(d) Sedativi
(e) Nesteroidni protuupalni lijekovi
(f) Druge farmakološki aktivne tvari

\section{Druge tvari i zagađivači okoliša}
(a) Organoklorni spojevi uključujući i PCB-e
(b) Organofosforni spojevi
(c) Kemijski elementi 
podrijetla koji su higijenski ispravni, a koji su namijenjeni stavljanju na tržište u cilju prehrane ljudi“ (Ministarstvo poljoprivrede, 2013.). Podjela tvari čije se rezidue određuju u sklopu monitoringa prema Pravilniku o monitoringu određenih tvari i njihovih rezidua u živim životinjama i u proizvodima životinjskog podrijetla NN 79/2008. prikazana je u tabeli 1.

$\mathrm{Na}$ razini Europe, Europska agencija za sigurnost hrane (EFSA, engl. European Food Safety Authority) iz tog razloga podnosi godišnje izvještaje o reziduama veterinarsko-medicinskih proizvoda u živim životinjama i proizvodima životinjskog podrijetla u svim zemljama članicama Europske unije. Prema posljednjem dostupnom izvješću za 2018. godinu, od 28 zemalja članica analizirano je 657818 uzoraka. Uzorkovanje, analiza uzoraka te općenita podjela tvari čije se rezidue određuju u pojedinim vrstama životinja su provedeni prema Direktivi Europske komisije br. 96/23 (Europska komisija, 1996.), od strane nacionalnih institucija odgovornih za provođenje plana monitoringa. Od ukupnog broja uzoraka dokazanojedajebrojnesukladnih uzoraka iznosio 1 059, odnosno, 0,30 \%, što je za 0,05 \% manje nego u 2017. godini. Vidljivo je lagano povećanje nesukladnosti za antitireoidne tvari, agense i steroide, a neznatno smanjenje nesukladnosti za antibakterijske lijekove, druge veterinarske lijekove (nesteroidni protuupalni lijekovi) te ostale tvari. Za ostale skupine tvari nije bilo znatnijih promjena (EFSA, 2020.b).

Zaključeno je da su dobiveni rezultati monitoringa u 2018. godini i dalje u velikoj sukladnosti s propisanim vrijednostima, ali i nadalje treba težiti smanjenju broja nesukladnih uzoraka (EFSA, 2020.a). Jedino je provođenjem redovitog i opsežnog monitoringa rezidua VMP-a u živim životinjama i proizvodima životinjskog podrijetla moguće ući u trag nesukladnim uzorcima te posljedično osigurati da meso, jaja, mlijeko i med na tržištu budu u potpunosti sigurni za konzumaciju.

\section{Sedativi}

Sedativi su veterinarsko-medicinski proizvodi koji prema Pravilniku o monitoringu određenih tvari i njihovih rezidua $u$ živim životinjama i $u$ proizvodima životinjskog podrijetla pripadaju skupini veterinarskih lijekova i kontaminanata, odnosno skupini drugih veterinarskih lijekova (skupini B) (tabela 1.) (Pravilnik, 2008.). Koristeu se s ciljem smanjenja uznemirenosti i ukupnog odgovora organizma na vanjske stimulanse (Maksimović i sur., 2018.). Prilikom uporabe sedativa nastupa centralna depresija i pospanost, a životinja nije ni svjesna okoline (Kos, 2008.). Koriste se u situacijama kada je potrebno obuzdati životinju (transport životinja, prilikom hvatanja i identifikacije, timarenja i čišćenja); u svrhu pregleda životinje; kao predmedikacija gdje se njihovom primjenom olakšava manipulacija životinjom, otklanja strah životinje i smanjuje doza anestetika potrebnih za opću anesteziju (Kos, 2008.), a koriste se osobito prilikom prijevoza životinja (Trevisani i sur., 2019.) i prije samog klanja da bi se spriječio stres životinje. Primjerice, preveliki stres svinja prije klanja može rezultirati nepoželjnim karakteristikama mesa koje kao takvo nije privlačno kupcima (Cerkvenik Flajs i MacNeil, 2017.).

Najčešća podjela sedativa je na ove skupine: fenotiazini, benzodiazepini, agonisti $\alpha 2$-adrenoreceptora, antagonisti $\alpha 2$-adrenoreceptora i butirofenoni (Kos, 2008.), a ace(to)promazin, azaperon, diazepam, haloperidol, karazolol, klorpromazin, ksilazin i propionilpromazin su najčešće korišteni sedativi (Cerkvenik Flajs i MacNeil, 2017.). 
Tabela 2. Kemijske strukture opisanih sedativa (PubChem, 2020.)

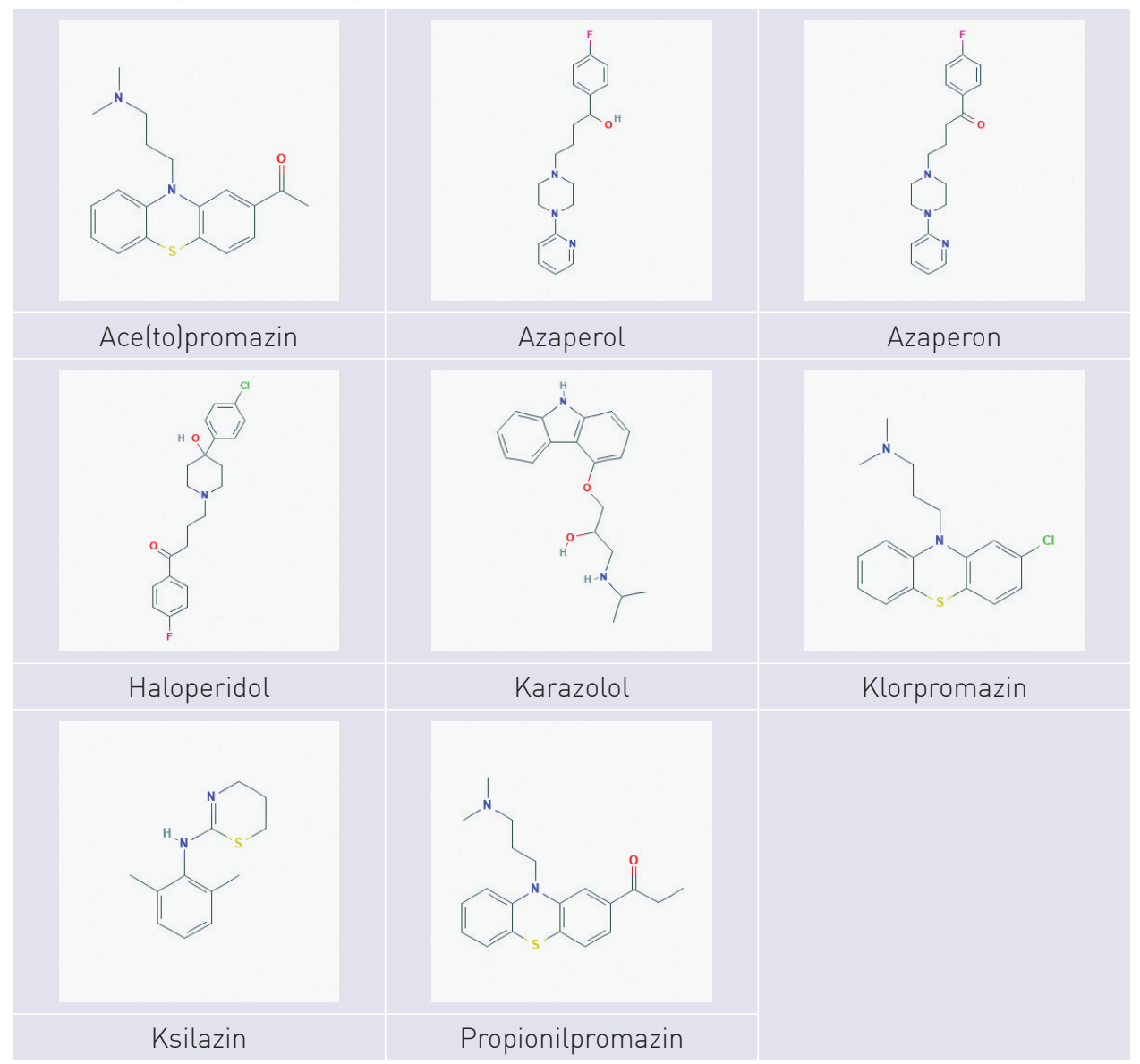

$\mathrm{Na}$ razini EU tijekom monitoringa rezidua VMP-a na živim životinjama i proizvodima životinjskog podrijetla provodi se i monitoring rezidua sedativa prema Direktivi Europske komisije br. 96/23 (Europska komisija, 1996.). Ako proučavamo godišnje izvješće EFSA-e o reziduama veterinarsko-medicinskih proizvoda u živim životinjama i proizvodima životinjskog podrijetla za 2018. godinu, primjećujemo da nije bilo nesukladnih uzoraka prilikom određivanja rezidua sedativa (EFSA, 2020.b). Isti podatci su bili i 2008. godine (EFSA, 2010.). Unatoč izvrsnoj usklađenosti nedavnih rezultata monitoringa $s$ najvišim dopuštenim količinama rezidua sedativa u hrani životinjskog podrijetla (EFSA, 2020.b), potrebno je naglasiti kako je rizik od zaostajanja rezidua sedativa $\mathrm{u}$ mesu tretiranih životinja realan (Trevisani i sur., 2019.). Treba naglasiti da pojedini sedativi za životinje nisu odobreni za uporabu na životinjama za proizvodnju hrane zbog velike mogućnosti zaostajanja rezidua te posljedično njihovog štetnog utjecaja na zdravlje potrošača (Cerkvenik Flajs i MacNeil, 2017.). Sedativi kao što su ace(to) promazin, haloperidol, klorpromazin i propionilpromazin nisu dopušteni za korištenje na životinjama za proizvodnju 
hrane (Cerkvenik Flajs i MacNeil, 2017.). Toksičnost klorpromazina i dugotrajna perzistencija njegovih rezidua je dokazana od strane Organizacije za hranu i poljoprivredu (FAO, engl. Food and Agriculture Organisation), Svjetske zdravstvene organizacije (WHO, engl. World Health Organisation) i Stručnog odbora za prehrambene aditive JECFA-e (engl. The Joint FAO/WHO Expert Committee on Food Additives) (WHO, 2019., FAO, 2020.), tako da je od velike važnosti da se redovitim monitoringom ustvrdi postoje li u uzorcima životinja i proizvoda životinjskog podrijetla rezidue klorpromazina, ali i drugih sedativa koji u Europi nisu odobreni za korištenje na životinjama za proizvodnju hrane.

U nastavku će biti opisano nekoliko sedativa koji se koriste na životinjama za proizvodnju hrane. Odabrani se sedativi često koriste te je mogućnost zaostajanja njihovih rezidua $\mathrm{u}$ tkivima $\mathrm{i}$ organima tretiranih životinja izgledna. Iako neki sedativi nisu dopušteni, a u uzorcima životinja i životinjskog podrijetla zbog česte zlouporabe se određuju, čime je određivanje njihovih rezidua od još veće važnosti.

Bit će opisane njihove karakteristike, način uporabe, utjecaj na životinje i vjerojatnost zaostajanja u obliku rezidua u organima i tkivima tretiranih životinja kao i propisane NDK vrijednosti. Isto tako, spomenut će se i ciljni organ ili tkiva u kojima se preporučuje procjena rezidua, odnosno mjesto u kojemu su rezidue korištenih sedativa najotpornije na razgradnju te se nalaze $u$ najvišim koncentracijama nakon njegove primjene na životinji. U tabeli 2. prikazane su njihove kemijske strukture.

\section{Ace(to)promazin}

Ace(to)promazin (ACP) (1-[10-[3-(dimetilamino)propil]fenotiazin-2-il]etanon) je acetilni derivat promazina (Clarke i Trim, 2014.) i najčešće je korišteni seda- tiv iz skupine fenotiazina (Kos, 2008.). Preporučen je za korištenje na psima, mačkama i konjima, dok njegova uporaba na životinjama za proizvodnju hrane još uvijek u Europskoj uniji, SAD-u i Kanadi nije odobrena (Cerkvenik Flajs i MacNeil, 2017.). U niskim dozama ovaj sedativ mijenja ponašanje životinje, povećavanjem doze određenje razine povećava se sedacija do određenog nivoa, nakon toga svako dodatno povećanje doze povećava dužinu sedacije, a samim time, popratne nuspojave (Kos, 2008.). Neki od negativnih nuspojava korištenja ace(to) promazina su: smanjenje krvnog tlaka, jačine udara i minutnog volumena srca životinje za 20-30 \% (Maksimović i sur., 2018.). U bikova i pastuha primijećene su negativne nuspojave na penis životinje koje posljedično mogu dovesti i do njegove amputacije, tako da se njihova uporaba na tim životinjama ne preporučuje (Kos, 2008.). Ne postoje službeni podatci o kratkoročnoj ili dugoročnoj toksičnosti ace(to)promazina na laboratorijskim životinjama (Crkvenik Flajs i MacNeil, 2017.), a još uvijek nije ni procijenjen od strane JECFA-e tako da nije poznato koje bi bilo ciljno tkivo za određivanje rezidua ace(to)promazina (WHO, 2019., FAO, 2020.). Neki stručnjaci predlažu kako bi ciljno tkivo trebalo biti masno tkivo, posebice ono s područja gdje je došlo do ubrizgavanja sedativa (Cerkvenik Flajs i MacNeil, 2017.).

\section{Azaperon}

Azaperon (1-(4-fluorofenil)-4-(4piridin-2-ilpiperazin-1-il)butan-1-on) pripada skupini butirofenona (Clarke i Trim, 2014.). Koristi se ponajprije na svinjama (Kos, 2008., Maksimović i sur., 2018.), a u kombinaciji s drugim lijekovima upotrebljava se i na divljim životinjama kao što su: jeleni, nosorozi, gazele i slonovi (Cerkvenik Flajs i MacNeil, 2017.). Može se primjenjivati i na govedima (Trevisani i sur., 2019.). 
Uporaba ovog sedativa nije preporučljiva na konjima (Clarke i Trim, 2014.). Koristi se kao sastavni dio predmedikacije $\mathrm{u}$ svinja, a najčešće se daje za sedaciju prije transporta, nakon miješanja svinja iz različitih legla (Kos, 2008.), u postupku spajanja mladih svinja $\mathrm{s}$ krmačom kad se prevenira agresivnost krmače (Maksimović i sur., 2018.) ili pri teškim i bolnim porodima (Cerkvenik Flajs i MacNeil, 2017.). Njegovom primjenom se postiže dobar stupanj sedacije koji je ovisan o dozi (Kos, 2008.). Prema Uredbi Europske komisije (2010.), NDK za azaperon je suma azaperona i azaperola. Azaperol ( $\alpha$-(4-fluorophenyl)-4-(2pyridinyl)-1-piperazine butanol) je najčešći metabolit azaperona. Njegova koncentracija $u$ tretiranim životinjama premašuje koncentracije unesenog azaperona te je njegovo izlučivanje iz organizma sporije nego izlučivanje izvornog lijeka. Zbog toga je potrebno određivati i koncentraciju njegovih rezidua prilikom određivanja rezidua azaperona (Cerkvenik Flajs i MacNeil, 2017.). NDK za mišiće, kožu i masno tkivo, jetru i bubrege svinja iznose 100 $\mu \mathrm{g} \mathrm{kg}^{-1}$ (Europska komisija, 2010.). Prema JECFA-i najviše dopuštene vrijednosti za mišiće i masno tkivo svinje iznose $60 \mu \mathrm{g}$ $\mathrm{kg}^{-1}$, dok su za jetru i bubrege vrijednosti jednake onima određenima Uredbom Komisije br. 37/2010 (Europska komisija, 2010.). JECFA je odredila i prihvatljiv dnevni unos (ADI, engl. Acceplatble Daily Intake) ovog sedativa kod ljudi koji iznosi 0-0,006 $\mathrm{mg} \mathrm{kg}^{-1}$ tjelesne mase. Također, JECFA smatra kako je azaperon malo vjerojatno genotoksičan ili kancerogen (WHO, 2019.). Vrlo brzo se izlučuje iz organizma. U tkivima i tjelesnim tekućinama životinja koje su zaklane četiri sata nakon primjene koncentracije rezidua azaperona i azaperola su bile niže od prosjeka. Neka istraživanja prikazuju zaostajanje rezidua azaperona $i$ azaperola $u$ najvećem udjelu $u$ bubrezima te jetri te se smatra kako se upravo ti organi trebaju analizirati za rezidue navedenog sedativa (Cerkvenik Flajs i MacNeil, 2017.).

\section{Haloperidol}

Haloperidol (4-[4-(4-klorofenil)-4hidroksipiperidin-1-il]-1-(4-fluorofenil) butan-1-on)) pripada skupini butirofenona. Koristi se kao sedativ kod hvatanja divljih životinja, dok u ljudi ima antipsihotički učinak (Cerkvenik Flajs i MacNeil, 2017.). Johns i sur. (2020.) su dokazali da se haloperidol može koristiti u pjegavog jelena (Axis axis) kao predmedikacija prije anestezije ksilazin-ketaminom jer uspješno smanjuje stres pri hvatanju životinje. Ovaj sedativ nije odobren za uporabu na životinjama za proizvodnju hrane, a još nema literaturnih podataka koji opisuju metabolizam haloperidola u govedima, svinjama, konjima ili ovcama. Neki autori sugeriraju da bi se potencijalno, ukoliko se primjenjuje kao lijek izvan odobrene upute (engl. Extra-label Drug Use), mogao koristiti na životinjama za proizvodnju hrane (Cerkvenik Flajs i MacNeil, 2017.). Lijek izvan odobrene upute označava uporabu odobrenog lijeka u svrhu koja nije u sukladnosti s onom koja mu je prvotno namijenjena i koja se nalazi na deklaraciji (npr. primjena na drugim vrstama životinja, u drugačijoj dozi ili načinu primjene) (Beyene, 2016.). No, svakako je bitno da se prije takve uporabe haloperidola ustvrdi da u organima i tkivima tretiranih životinja neće zaostati rezidue prije klanja. Ciljni organi za analizu haloperidola su: pluća, bubrezi i jetra. U svakom je organu drugačija raspodjela njegovih metabolita (Cekvenik Flajs i MacNeil, 2017.).

\section{Karazolol}

Karazolol (1-(9H-karbazol-4-iloksi)3-(propan-2-ilamino)propan-2-ol) je hipnotički sedativ koji je odobren za 
korištenje u svinja i goveda (Trevisani i sur., 2019.), a osim toga se primjenjuje i u humanoj medicini (Cerkvenik Flajs i MacNeil, 2017.). U veterinarskoj medicini se primjenjuje kada je potrebno smiriti životinju, primjerice kod pojave mastitisa, za ublažavanje tahikardije ili za smanjenje bijesa prilikom parenja. Razdoblje karence za meso svinja je od jedan do 12 sati, dok je za meso goveda jedan dan te za mlijeko 12 h (Cerkvenik Flajs i MacNeil, 2017.). Prema Uredbi Komisije (2010.), najviše dopuštene količine $u$ svinja iznose: $5 \mu \mathrm{g} \mathrm{kg}{ }^{-1}$ za mišiće, kožu i masno tkivo te $25 \mu \mathrm{g} \mathrm{kg}{ }^{-1} \mathrm{za}$ jetru i bubrege. Za goveda su dopuštene ove vrijednosti NDK: $5 \mu \mathrm{g} \mathrm{kg}^{-1}$ za mišiće i masno tkivo, $15 \mu \mathrm{g} \mathrm{kg}^{-1} \mathrm{za}$ jetru i bubrege te $1 \mu \mathrm{g} \mathrm{kg}{ }^{-1}$ za mlijeko. Budući da se ovaj sedativ koristi i u humanoj medicini, njegove rezidue predstavljaju opasnost za ljudsko zdravlje. No, prednost je što se vrlo brzo nakon intramuskularne primjene preporučene doze $\left(10 \mu \mathrm{g} \mathrm{kg}^{-1}\right)$ eliminira iz svih tkiva. Preporuka je da bubrezi te mjesto ubrizgavanja ovog sedativa budu ciljna tkiva za određivanje njegovih rezidua (Cerkvenik Flajs i MacNeil, 2017.). JECFA je odredila i akutnu referentnu dozu (ARfD, engl. Acute Reference Dose) od 0,0001 $\mathrm{mg} \mathrm{kg}^{-1}$ tjelesne mase. Budući da rezidue karazolola mogu zaostati na mjestu ubrizgavanja do dva sata nakon primjene, čije rezidue premašuju vrijednost ARfD-a, preporuka je da se karazolol ne koristi prilikom transporta životinja na klanje (WHO, 2019.).

\section{Klorpromazin}

Klorpromazin (3- (2-klorofenotiazm10-il)-N,N-dimetilpropan-1 amin) je sedativ koji se prema Uredbi Komisije (2010.) nalazi u skupini zabranjenih tvari čiju najvišu dopuštenu količinu nije moguće ustvrditi. $\mathrm{Na}$ temelju rezultata evaluacije od strane JECFA-e, klorpromazin se dokazao potencijalno genotoksičnim te neurotoksičnim sa štetnim učincima na reproduktivni sustav (WHO, 2019.). JECFA zbog „nedostatka relevantnih toksikoloških podataka, dugotrajne perzistencije $u$ ljudi, spektra dodatnih učinaka lijeka i vjerojatnosti da čak i male doze mogu prouzročiti promjene $u$ ponašanju“ nije odredila ADI (WHO, 2019., FAO, 2020.). Ne preporučuje se za uporabu na konjima (Papich, 2016.) u kojih su primijećeni metaboliti klorpromazina $\mathrm{u}$ urinu do čak $96 \mathrm{~h}$ nakon oralnog ili intravenskog unosa (Cerkvenik Flajs i MacNeil, 2017.). Zbog nedostatka informacija još uvijek nije preporučeno ciljno tkivo za određivanje rezidua klorpromazina, iako neki stručnjaci preporučuju mjesto ubrizgavanja te bubrege ili jetru kao potencijalne ciljne organe (Cerkvenik Flajs i MacNeil, 2017.).

\section{Ksilazin}

Ksilazin (N- (2,6-dimetilfenil)-5,6dihidro-4H-1,3-tiazin-2-amin) je agonist $\alpha 2$-adrenoreceptora koji se koristi u malih i velikih životinja kao sedativ, sredstvo za predmedikaciju, mišićnu relaksaciju ili kao analgetik (Cerkvenik Flajs i MacNeil, 2017.). U kombinaciji s ketaminom može se koristiti i za održavanje anestezije (Maksimović i sur., 2018.) u konja, goveda, pasa, mačaka i većine laboratorijskih životinja (Kos, 2008.). Postoje velike razlike u potrebnim dozama između pojedinih životinjskih vrsta, gdje su se goveda pokazala najosjetljivijom vrstom s obzirom da im je potrebna niža doza nego drugim životinjama (Cerkvenik Flajs i MacNeil, 2017.). Konjima kojima je potrebna do deset puta veća doza nego govedima i stupanj sedacije je manji (Kos, 2008.). Studije na konjima, govedima i štakorima pokazale su vrlo brz metabolizam ksilazina, no njegova uporaba je ograničena ili zabranjena $u$ mnogim zemljama (Cerkvenik Flajs i MacNeil, 2017.). Prema Uredbi Komisije br. 37/2010., NDK rezidua ksilazin 
hidroklorida nije potrebna $\mathrm{u}$ kopitara i goveda (Europska komisija, 2010.). JECFA isto tako nije odredila NDK, jer su informacije o reziduama ksilazina nepotpuneinedovoljne.ADInije određen, jer je Odbor zaključio kako je metabolit ksilazina (2,6-ksilidin) genotoksičan i kancerogen (WHO, 2019.). Prema Papich (2016.), vrijeme karence za goveda pri primijenjenoj dozi od 0,016 $\mathrm{mg} \mathrm{kg}^{-1}$ je pet dana za meso te $72 \mathrm{~h}$ za mlijeko. Za dozu 0,05-0,3 mg kg-1 ona iznosi deset dana za meso i 120 h za mlijeko. Neki autori preporučuju praćenje rezidua ksilazina preko mjesta ubrizgavanja ili bubrega (Cerkvenik Flajs i MacNeil, 2017.).

\section{Propionilpromazin}

Propionilpromazin (1-[10-[3-(dimetilamino)propil]fenotiazim-2-il]propan1-on), poznat kao i propiopromazin (Cerkvenik Flajs i MacNeil, 2017.), je sedativ koji se koristi u malih i velikih životinja (Clarke i Trim, 2014.) da bi se smanjili stres i patnja, posebice u svinja tijekom transporta do klaonice (Cerkvenik Flajs i MacNeil, 2017.). Može se koristiti i kao predmedikacija (Clarke i Trim, 2014.). Zbog nedostataka informacija o farmakološkom i toksikološkom utjecaju ovog sedativa, JECFA nije odredila najvišu dopuštenu količinu rezidua kao ni ADI. Odbor je s svjestan da se ovaj sedativ koristi u okolnostima u kojima će potrošač biti izložen reziduama koji bi mogli imati farmakološki učinak, tako da nije preporučio uporabu propionilpromazina u životinja za proizvodnju hrane, a ni JECFA nije uspjela identificirati ciljno tkivo za praćenje rezidua (WHO, 2019.). Neka istraživanja su pokazala da je u svinja tretiranih propionilpromazinom najviša količina rezidua zadržana u masnom tkivu vrata te masnom tkivu oko bubrega, dok su niže koncentracije pronađene $\mathrm{u}$ jetri, a znatno niže u mišićima. Prema nedavnoj studiji autori preporučuju da se uzorci za određivanje rezidua uzimaju s područja masnog tkiva gdje je došlo do ubrizgavanja sedativa (Cerkvenik Flajs i MacNeil, 2017.).

\section{Analitičke metode za određivanje rezidua sedativa}

S obzirom da ciljno tkivo/organ za određivanje rezidua sedativa ovisi o mnogo čimbenika, ponajviše o vrsti upotrijebljenog sedativa, potrebno je bilo uspostaviti standard za njihovo određivanje. Prema većini dostupnih literaturnih podataka, ispostavilo se da su bubrezi organi $u$ kojemu postoje

Tabela 3. Marker supstance za određivanje sedativa te propisane NDK vrijednosti za bubrege životinja (Europska komisija, 2010.)

\begin{tabular}{|c|c|c|c|}
\hline Vrsta sedativa & Marker supstanca & Životinjska vrsta & NDK $\left(\mu \mathrm{g} \mathrm{kg}{ }^{-1}\right)$ \\
\hline Aceltolpromazin & Osnovna supstanca & Sve & Zabranjen \\
\hline Azaperon & Suma Azaperon + Azaperol & Svinja & 100 \\
\hline Haloperidol & Osnovna supstanca & Sve & Zabranjen \\
\hline Karazolol & Osnovna supstanca & $\begin{array}{l}\text { Govedo } \\
\text { Svinja }\end{array}$ & $\begin{array}{l}15 \\
25\end{array}$ \\
\hline Klorpromazin & Osnovna supstanca & Sve & Zabranjen \\
\hline Ksilazin & Osnovna supstanca & Sve & - \\
\hline Propionilpromazin & Osnovna supstanca & Sve & Zabranjen \\
\hline
\end{tabular}


najviše mjerljive koncentracije rezidua sedativa, iako neki stručnjaci predlažu i mišiće kao ciljno tkivo (Cerkvenik Flajs i MacNeil, 2017.). U tabeli 3. nalazi se sažet prikaz opisanih sedativa koji se određuju prilikom monitoringa s odgovarajućim marker supstancama za određivanje njihovih rezidua $\mathrm{u}$ bubrezima životinja te određenim NDK vrijednostima prema Uredbi Komisije br. 37/2010 (Europska komisija, 2010.).

Monitoring je potrebno provoditi korištenjem provjerenih i pouzdanih analitičkih metoda pomoću kojih će se, ukoliko su prisutni, odrediti točna količina rezidua (Europska komisija, 2001.) kao i osigurati njihova nedvojbena identifikacija (Cannavan i sur., 2017.). U kontroli se primjenjuju orijentacijske i potvrdne metode. Orijentacijske (engl. Screening) metode dokazuju prisutnost neke tvari na razini značajnosti, a nisu dovoljne prilikom određivanja organskih rezidua i kontaminanata. Ove metode karakterizira sposobnost brze obrade velikog broja uzoraka i otkrivanja mogućih pozitivnih rezultata. Sumnjivi i pozitivni uzorci idu na daljnju analizu kvantitativnom potvrdnom metodom koja omogućuje potpune podatke o tvari na temelju kojih će se istu moći nedvojbeno identificirati i po potrebi kvantificirati (Europska komisija, 2002.). Potvrdne metode karakterizira visoka osjetljivost, niska granica određivanja, selektivnost, preciznost i brzina analize.

$\mathrm{Za}$ određivanje rezidua sedativa u biološkim uzorcima dostupno je nekoliko analitičkih metoda (Cerkvenik Flajs i MacNeil, 2017.). Prije nego li se krene $\mathrm{u}$ analizu, potrebno je poznavati farmakološka svojstva sedativa, način unosa sedativa, njegov metabolizam i raspodjelu unutar životinjskog organizma, reprezentativni (ciljni) organ/ tkivo koji će se analizirati te dati „pravu sliku" o koncentraciji rezidua i njihovom zadržavanju unutar organizma (MacNeil i Kay, 2017.). Kod provođenja analiza na rezidue sedativa, najčešće se kao ciljno tkivo, odnosno organi, uzimaju bubrezi (Cerkvenik Flajs i MacNeil, 2017.). Prema dostupnoj literaturi: neke od metoda koje se koriste $u$ određivanju rezidua sedativa u biološkim uzorcima su: kromatografske metode (tekućinska kromatografija (LC, engl. Liquid Cromatography), tankoslojna kromatografija (TLC, engl. Thin Layer Chromatography) ili plinska kromatografija (GC, engl. Gas Cromatography)) te imunološki testovi (ELISA, engl. EnzymeLinked Immunosorbent Assay) (Cerkvenik Flajs i MacNeil, 2017.). Primjerice, Copper i sur. su uz pomoć ELISA metode odredili ostatke šest vrsta sedativa $u$ svinjskim bubrezima (Cooper i sur., 2004.). Ona omogućava brzu detekciju i razlučivanje negativnih i potencijalno pozitivnih rezultata (Cerkvenik Flajs i MacNeil, 2017.), jednostavno se koristi i dostupni su kitovi za velik broj specifičnih komponenti (Toldrá i Reig, 2006.). Glavni nedostatak ove metode, koji je ujedno i glavni razlog njezine rijetke uporabe u ove svrhe, je potreba za dodatnim korištenjem potvrdnih metoda kod dobivanja pozitivnih rezultata (Cerkvenik Flajs i MacNeil, 2017.).

Devedesetih godina prošlog stoljeća HPLC (engl. High Performance Liquid Chromatography) metoda s fluorescentnim i/ili UV-detektorom bila je dominantna analitička metoda za određivanje rezidua sedativa (Toldrá i Reig, 2006.). Razvitkom tehnologije ova se metoda danas sve rjeđe koristi. Smatra se da bi kombinacijom navedenih detektora, ova metoda mogla biti dostojna zamjena u situacijama kada nije dostupan maseni spektrometar (Cerkvenik Flajs i MacNeil, 2017.).

Maseni spektrometar se zbog svojih svojstava $u$ današnje vrijeme smatra gotovo obveznim prilikom određivanja rezidua sedativa, ali i rezidua drugih kontaminanata $\mathrm{u}$ biološkim uzorcima. Tako je i većina metoda koje se koriste za određivanje rezidua sedativa temeljeno na tekućinskoj kromatografiji povezanoj 
s masenom spektrometrijom (engl. Mass Spectrometry - MS) - LC-MS/MS (Cerkvenik Flajs i MacNeil, 2017., Rocca i sur., 2017.). Razvojem tehnologije, posljednjih se godina sve više koristiti tekućinska kromatografija ultra visoke djelotvornosti (UHPLC, engl. Ultra High Performance Liquid Chromatohraphy) koja se odlikuje visokom razlučivosti, osjetljivosti i preciznosti (Dong i Zhang, 2014.). U odnosu na HPLC metodu, UHPLC s kraćim vremenom analize i bržim uravnoteženjem kolona idealna kod brzog razvoja metoda, budući da uporaba UHPLC metode znatno povećava produktivnost $\mathrm{u}$ svim fazama razvoja metode od inicijalnog ispitivanja, optimizacije, do kvalifikacije i validacije (Dong i Zhang, 2014.).

UHPLC-MS/MS metoda je metoda koja se zasniva na kombinaciji tekućinske kromatografije visoke djelotvornosti te masene spektrometrije. Tekućinska se kromatografija visoke djelotvornosti temelji na prolasku sastojaka uzorka $\mathrm{u}$ obliku otopine $\mathrm{u}$ struji mobilne faze, pod visokim tlakom, kroz kromatografsku kolonu koja je ispunjena česticama stacionarne faze. Na temelju specifičnih fizikalno-kemijskih svojstava sastojaka uzorka te njihovih interakcija sa stacionarnom, tj. mobilnom fazom, analizirani sastojci se različito vrijeme zadržavaju u koloni čime dolazi do njihova razdvajanja. Tekućinski kromatograf i spektrometar masa povezani su međuspojem (engl. Interface) koji ima višestruku ulogu: otparavanje tekućine, ionizacije neutralnih molekula i uvođenje analita u analizator. Elektrosprej ionizacija (ESI, engl. Electrospray Ionization) je jedan od najzastupljenijih načina ionizacije $u$ vezanom sustavu LC-MS koji je kompatibilan sa svim analizatorima. Ionizacija može biti pozitivna $\mathrm{i}$ negativna (u ovisnosti o naponu na kapilari i kolektorskoj elektrodi), a ionizacija i nebulizacija se događaju pri atmosferskom tlaku.
Optimalna temperatura ionizacije je iznad $100{ }^{\circ} \mathrm{C}$ i događa se u struji dušika. Ionizacija se odvija tako da pokretna faza $\mathrm{i}$ analit ulaze $\mathrm{u}$ ionizator kroz kapilaru (iglu), koja predstavlja i elektrodu pod visokim naponom (Cindrić i sur., 2009.). $\mathrm{Na}$ uzorak djeluje jako električno polje (stvara se između igle i elektrode kroz koju prolazi) te zbog razlike potencijala nastaju nabijene kapljice. Daljnjim isparavanjem kapliica nastaju ioni. Nakon ionizacije nabijeni ioni ulaze $u$ maseni spektrometar.

Masena se spektrometrija smatra najznačajnijim analitičkim postupkom u suvremenoj analizi. Princip se rada temelji na analizi molekula na osnovi njihovog omjera mase i naboja, $\mathrm{m} / \mathrm{z}$. U kvantitativnoj analizi prevladavaju spektrometri masa s dva analizatora (Q1 i Q3), sastoje se od četiri paralelne šipke tzv. kvadrupoli, koje se nalaze pod određenim naponom istosmjerne struje (DC, engl. Direct Current) i radiofrekvencije (RF, engl. Radiofrequency), između kojih se nalazi kolizijska ćelija koja predstavlja dodatni kvadrupol iako se radi o heksapolu (Q3) te formiraju tzv. trostruki kvadrupol (QQQ, engl. Triple Quadrupol). Kvadrupoli se koriste kao maseni filteri, budući da se ovisno o primjeni zadanih DC i RF napona propuštaju ioni određene $m / z$ vrijednosti kroz kvadrupol do detektora. Maseni detektor pristigle ione pretvara $u$ elektronske signale te se na računalu dobiva kromatografski pik.

Postoje brojni literaturni podatci o učinkovitosti (U)HPLC-MS/MS metode za određivanje sedativa, ali i drugih vrsta veterinarskih lijekova. Tako su Robert i sur. (2013.) uspješno dokazali da se ova metoda može primijeniti za određivanje širokog raspona rezidua veterinarskih lijekova (antihelmintika, beta-agonista, antibiotika, nesteroidnih protuupalnih lijekova, sedativa $\mathrm{i}$ dr.) na uzorcima jaja, mlijeka, meda i mišića životinja. Isto tako, De Oliveira i sur. (2016.) LC-MS/MS nazivaju jednostavnom i 
jeftinom metodom koja se može koristiti za određivanje pet vrsta sedativa (acepromazin, azaperol, azaperon, karazolol, klorpromazine i kslazine) i 14 vrsta beta-blokatora u bubrezima svinja, goveda i konja.

Može se reći da je UHPLC-MS/ MS metoda zbog svoje selektivnosti u kombinaciji s velikom osjetljivošću postala standard za određivanje rezidua veterinarskih lijekova te se stalno unaprjeđuje (Rocca i sur., 2017.).

\section{Literatura}

1. BEYENE, T. (2016): Vetenary drugs residues in foodanimal products: its factors and potential effect on public health. J. Veterinar. Sci. Technol. 7, 1-7.

2. CANNAVAN, A., J. F. KAY and Z. JANDRIĆ (2017): Method Validation and Quality Assurance/Quality Control Approaches for Multi-residue Methods. In: Kay, J. F., J. D. MacNeil and J. Wang (ed.): Chemical Analysis of Non-antimicrobial Veterinary Drug Residues in Food, JohnWiley \& Sons, Inc., Hoboken, New Jersey, USA, pp. 549-569.

3. CERKVENIK FLAJS, V. and J. D. MACNEIL (2017): Sedatives and Tranquilizers. In: Kay, J. F., J. D MacNeil, J. Wang (eds.): Chemical Analysis of Nonantimicrobial Veterinary Drug Residues in Food, JohnWiley \& Sons, Inc., Hoboken, New Jersey, USA, pp. 311-362.

4. CINDRIĆ, M., A. MARKOVIĆ i A. HORVATIĆ (2009): Spregnute tehnike tekućinski kromatografspektrometar masa: osnovne metodologije i primjene. Medicina 45, 218-232.

5. CLARKE, K. and C. TRIM (2014): Veterinary Anaesthesia, 11 ed., Saunders Elsevier Ltd., pp. 81-82.

6. COPPER, J., P. DELAHANT, T. L. FODEY and C. T. ELLIOTT (2004): Development of a rapid screening test for veterinary sedatives and beta-blocker carazolol in porcine kidney by ELISA. Analyst 29, 169-174.

7. DE OLIVEIRA, L. G., F. BARRETO, R. HOFF, G. RÜBENSAM, M. H. SHERER KURZ, G GALLE and F. GONÇALVES (2016): Validation of a method for sedatives and $\beta$-blockers determination in swine, bovine and equine kidney using LC coupled with tandem MS. Food Addit. Contam. A 37, 32-39.

8. DONG, M. W. and K. ZHANG (2014): Ultra-high pressure liquid chromatography (UHPLC) in method development. TrAC - Trend. Anal. Chem. 63, 21-30.

9. EFSA (2010): Report for 2008 on the results from the monitoring of veterinary medicinal product residues and other substances in food of animal origin in the Member States. EFSA Journal 8, 1-55.

10. EFSA (2020a): Veterinary drug residues in animals and food: compliance with safety still high. EFSA
- European Food Safety Authority, <http://www. efsa.europa.eu/en/news/veterinary-drug-residuesanimals-and-food-compliance-safety-levels-stillhigh>. Pristupljeno 05. svibnja 2020.

11. EFSA (2020b): Report for 2018 on the results from the monitoring of veterinary medicinal product residues and other substances in live animals and animal products. EFSA Supporting Publications 17, 1-74.

12. Europska komisija (1996): Direktiva Vijeća 96/23/EZ od 29. travnja 1996. o mjerama za nadzor određenih tvari i njihovih rezidua u živim životinjama i proizvodima životinjskog podrijetla i ukidanju Direktiva 85/358/EEZ i 86/469/EEZ i Odluka 89/187/ EEZ i 91/664/EEZ. Off. J. Eur. Commun. L 125. 10-32.

13. Europska komisija (2001): Direktiva 2001/82/EZ Europskog parlamenta i vijeća od 6. studenog 2001. o zakoniku Zajednice o veterinarsko-medicinskim proizvodima. Off. J. Eur. Commun. L 311. 030, 76-141.

14. Europska komisija (2002): Commission Decision 2002/657/EC of 12 August 2002 implementing Council Directive 96/23/EC concerning the performance of analytical methods and the interpretation Off. J. Eur. Commun. L 221, 8-28.

15. Europska komisija (2010): Uredba komisije br. $37 / 2010$ od 22. prosinca 2009. o farmakološki djelatnim tvarima i njihovoj klasifikaciji u odnosu na najveće dopuštene količine rezidua $\mathrm{u}$ hrani životinjskog podrijetla. Off. J. Eur. Commun. L 15. 032, 275-346.

16. FALOWO, A. B. and O. F. AKIMOLADUM (2019): Veterinary Drug Residues in Meat and Meat Products: Occurrence, Detection and Implications. In: Bekoe, S. M., R. K. Adosraku, M. Saravanan and P. K. Ramkumar (eds.): Veterinary Medicine and Pharmaceuticals, IntechOpen, pp. 1-18.

17. FAO (2020): JECFA databases, Online edition „Residues of some veterinary drugs in food and animals", FAO - Food and Agriculture Organisation, <http://www.fao.org/food/foodsafety-quality/scientific-advice/jecfa/jecfavetdrugs/en/>. Pristupljeno 16. lipnja 2020.

18. JOHNS, J., N. CAULKETT, G. CHANDY, J. ALEKSANDER, S. K. VENUGOPAL, S. SURENDRAN and A. SREEDHARANNAIR (2020): Oral haloperidol predmedication to reduce capture stress prior to xylazine-ketamine anesthesia in captive spotted deer (Axis axis). J. Zoo Wildl. Med. 51, 88-95.

19. KOS, J. (2008): Uvod u anesteziologiju. Premedikacija i sedacija. Podjela anestezije. Lokalna i regionalna anestezija. Intavenska anestezija., Klinika za kirurgiju, ortopediju i oftalmologiju, Veterinarski fakultet, Sveučilište u Zagrebu, Zagreb.

20. MACNEIL, J. D. and J. F. KAY (2017): Basic Consideration for the Analyst for Veterinary Drug Residue Analysis in Animal Tissues. In: Kay, J. F., J. D. MacNeil and J. Wang (eds.): Chemical Analysis of Non-antimicrobial Veterinary Drug Residues in Food, JohnWiley \& Sons, Inc., Hoboken, New Jersey, USA, pp. 1-21.

21. MAKSIMOVIĆ, A., I. LUTVIKADIĆ, S. FILIPOVIĆ i DŽ. HADŽIJUNUZOVIĆ-ALAGIĆ (2018): Analgetici, sedativi i anestetici u veterinarskoj 
medicini sa referentnim protokolima, Veterinarski fakultet Sarajevo, Sarajevo, str. 18-22.

22. Ministarstvo poljoprivrede (2013): Uprava za veterinarstvo i sigurnost hrane: Praćenje rezidua/ Državni plan monitoringa rezidua (DPMR), <http:// www.veterinarstvo.hr/default.aspx?id=123>. Pristupljeno 23. lipnja 2020.

23. PAPICH, M. G. (2016): Saunders Handbook of Veterinary Drugs: Small and Large Animal, $4^{\text {th }}$ edition, Elsevier, USA, pp. 153-154.

24. PRAVILNIK (2008): Pravilnik o monitoringu određenih tvari i njihovih rezidua $u$ živim životinjama i u proizvodima životinjskog podrijetla. Narodne novine 79, Zagreb.

25. PUBCHEM (2020): Open chemistry database at the National Institutes of Health (NIH), <https://pubchem. ncbi.nlm.nih.gov/>. Pristupljeno 25. kolovoza, 2020.

26. ROBERT, C., N. GILLARD, P.-Y. BRASSEUR, G. PIERRET, N. RALET, M. DUBOIS and PH. DELAHAUT (2013): Rapid multi-residue and multi-class qualitative screening for veterinary drugs in foods of animal origin by UHPLC-MS/MS. Food Addit. Contam. A 30, 443-457.
27. ROCCA, L. M., A. GENTILI, V. PÉREZFERNÁNDEZ and P. TOMAI (2017): Veterinary drugs residues: a review of the latest analytical research on sample preparation and LC-MS based methods. Food Addit. Contam. A 34, 1-39.

28. TOLDRÁ, F. and M. REIG (2006): Methods for rapid detection of chemical and veterinary drug residues in animal food. Trends Food Sci. Tech. 17, 482-489.

29. TREVISANI., M., G. FEDRIZZI and G. DIEGOLI (2019): Chemical hazards in meat and associated monitoring activities. In: Smulders, F. J. M., I. M. C. M. Rietjens, M. D. Rose (eds.): Food safety assurance and veterinary public health, volume 7 - Chemical hazards in food of animal origin Wageningen Academic Publishers, Netherlands, pp. 315-340.

30. WHO (2019): Evaluations of the Joint FAO/WHO Expert Committee on Food Additives (JECFA), Database, WHO - World Health Organisation, <https://apps.who.int/food-additivescontaminants-jecfa-database/search.aspx> Pristupljeno 18. lipnja, 2020.

31. ZAKON (2013): Zakon o veterinarstvu. Narodne novine 82 , Zagreb.

\section{Sedatives in veterinary medicine and their determination}

Ada PUNTARIĆ, MSc in Food Safety Management, Faculty of Food Technology and Biotechnology, University of Zagreb, Croatia; Đurđica BOŽIĆ LUBURIĆ, Grad. Biotechnology Eng., Ivana VARENINA, PhD, Grad. Biotechnology Eng., Scientific Associate, Nina BILANDŽIĆ, $\mathrm{PhD}$, Grad. Biotechnology Eng., Scientific Advisor in Tenure, Croatian Veterinary Institute, Zagreb, Croatia; Marina KRPAN, PhD, Associate Professor, Mirjana HRUŠKAR, PhD, Grad. Biotechnology Eng., Full Professor, Faculty of Food Technology and Biotechnology, University of Zagreb, Croatia

Sedatives, as veterinary medicinal products used on food-producing animals just before slaughter, pose a potential risk to consumer health due to the increased possibility of the presence of their residues in products of animal origin. For public health protection purposes, the regular control of food products, using adequate and reliable analytical methods to detect possible deviations from the prescribed values, is of high importance. The lag of sedative residues in the body of treated animals depends on many factors, such as the type of sedative used, type of animal receiving the sedative, initial dose, method and place of administration, and animal's overall health, etc. It is essential to establish the target organ or tissue for their determination. Based on the literature data, the kidney is the most commonly examined target organ, and gives a true picture of the amount of residue present. Analytical methods used to determine sedative residues can be screening (immunoassays - ELISA) or confirmatory (chromatography methods such as gas, thin layer, liquid chromatography/ liquid chromatography coupled with mass spectrometry). Nevertheless, the standard for their determination is liquid chromatography coupled with mass spectrometry. This method is the most reliable for determining residues of various contaminants in biological samples, not only sedatives. Nowadays, ultra high performance liquid chromatography (UHPLC) is increasingly used, thanks to its higher sensitivity, precision and resolution compared to conventional liquid chromatography. Therefore, the UHPLC-MS/MS method with its high sensitivity and selectivity outperforms other available methods. This paper describes some of the most commonly used sedatives in food-producing animals, and ways to determine their residues.

Key words: monitoring; residues; sedatives; UHPLC-MS/MS; veterinary medicinal products 